DOI: https://doi.org/10.36910/6775-2524-0560-2021-44-11

УДК 658.512

Філь Наталія Юріївна, к.т.н., доцент

https://orcid.org/0000-0003-2081-7176

Кудирко Ольга Миколаївна, асистент.

https://orcid.org/0000-0002-0858-9580

Харківський національний автомобільно-дорожній університет, м. Харків, Україна.

\title{
НЕЧІТКА МОДЕЛЬ РОЗПОДІЛУ РОБІТ МІЖ ПРАЦІВНИКАМИ НА СКЛАДІ ПІДПРИЕМСТВА
}

Філь Н. Ю., Кудирко О.М. Нечітка модель розподілу робіт між працівниками на складі підприємства. Розроблено нечітку модель розподілу робіт між працівниками. Наведено приклад розподілу робіт між працівниками на складі підприємства з застосуванням теорії нечітких множин. Використання моделі дозволяє оптимально розподілити роботи між працівниками відповідно до принципу поєднання можливістей і бажаність, комплексно врахувати їх знання та досвід, психофізіологічне профілювання, а також знизити їх завантаженість. Розрахунки виконувалися в Microsoft Excel.

Ключові слова: склад, нечітка множина, функція належності, психофізіологічні характеристики кандидатів, посади, Microsoft Excel.

Филь Н.Ю., Кудырко О.Н. Нечеткая модель распределения работ между работниками на складе предприятия Разработана нечеткая модель распределения работ между работниками. Приведен пример распределения работ между работниками на складе предприятия с применением теории нечетких множеств. Использование модели позволяет оптимально распределить работы между работниками в соответствии с принципом сочетания возможностей и желательности, комплексно учесть их знания и опыт, психофизиологическое профилирование, а также снизить их загруженность. Расчеты выполнялись в Microsoft Excel.

Ключевые слова: склад, нечеткое множество, функция принадлежности, психофизиологические характеристики кандидатов, должности, Microsoft Excel.

Fil N., Kudyrko O. A fuzzy model for distributing work between workers in the warehouse of an enterprise. A fuzzy model for distributing work between employees has been developed. An example of the distribution of work between workers in the warehouse of the enterprise using the theory of fuzzy sets is given. Using the model allows optimal distribution of work between employees in accordance with the principle of combining opportunities and desirability, comprehensively take into account their knowledge and experience, psychophysiological profiling, and also reduce their workload. Calculations were performed in Microsoft Excel.

Keywords: composition, fuzzy set, membership function, psychophysiological characteristics of candidates, positions, Microsoft Excel.

Постановка наукової проблеми. У сучасній світовій економіці все більшу увагу приділяють підвищенню ефективності роботи складів різних підприємств.

Склад є складною системою зі своїми взаємозв'язками та внутрішніми процесами. Основна та першочергова мета створення складів підприємств полягає в розміщенні та зберіганні товарноматеріальних цінностей, своєчасному забезпеченні виробництва необхідною сировиною, матеріалами та комплектуючими для здійснення безперебійного виробничого циклу [1]. Сьогодні роль складів у логістичній системі підприємства країни змінилася. На даному етапі розвитку економіки склад підприємства виступає цілісною та необхідною ланкою логістичного ланцюга підприємства, крізь яке відбувається перетворення та переміщення матеріальних ресурсів.

Розглянемо позитивні і негативні сторони складського господарства.

Забезпечення вирівнювання виробництва, розподіл і концентрація запасів, створення необхідних технічних та організаційних умов для комплектації вантажів - це позитивна роль складування [2].

Негативною стороною складування є збільшення вартості товару за рахунок витрат з утримання запасів на складах. У такі витрати входить оренда складу, витрати на його утримання і т.д.

Зберігання та концентрація запасів, забезпечення ритмічного та безперебійного постачання замовлень до споживачів - основне призначення складів [2].

Склад є лише елементом системи вищого рівня - логістичного ланцюга підприємства, який формує основні та технічні вимоги до складської системи, встановлює цілі та критерії ії оптимального функціонування [2]. Для оптимального функціонування складські технологічні процедури повинні бути оптимально сплановані.

Сучасний склад обов'язково оснащено автоматизованою системою контролю за складськими процедурами й управління обліком потоку товарних і грошових цінностей. [3]. Використання системи 
автоматизації складу значно збільшує дієвість роботи складу, зменшує необхідні об'єми резервів $\mathrm{i}$ збільшує товарообіг, зменшує період виконання складських процедур і максимізує їх чіткість.

Підвищення вимог до ефективності складських процесів через зростання конкуренції та темпів бізнесу, оптимізація витрат, дефіцит складських кадрів - такі реалії сучасної складської логістики дистриб'юторів, виробників і рітейлерів [3].

Кількість працівників, які обслуговують склад, і устрій апарату персоналу в основному залежать від обсягів товарообігу, переліку товару, який зберігаються на складі підприємства. Найбільш важливими тенденціями координації роботи на складі підприємства є: дослідження розумних форм роздроблення й об'єднання роботи складського персоналу, координація та сервіс робочих місць, дослідження та розподіл нових прийомів і методик роботи при виконанні складських процедур, раціональна організація та підвищення кваліфікації персоналу, розробка відповідних умов роботи та техніка безпеки [4].

Пандемія заморозила розвиток складського ринку, замістивши поточну модернізацію екстреної адаптацією до мінливих умов.

Пандемія привела до різкого збільшення кількість клієнтів е-сommerce, особливо в великих містах. Логістичним компаніям доводилось адаптуватися під нові вимоги, розширюватися, проводити модернізацію складського господарства, щоб зробити термінали не тільки зручними, але і безпечними для клієнтів.

Під час пандемії були впроваджені такі методи підвищення ефективності складів:

- підвищення щільності зберігання на 1 кв. м., тобто ущільнення зберігання в комірках;

- оптимізація технологічних процесів обробки транспортних засобів;

- оптимізація процесу підбору вантажу на замовлення [5].

Все це дозволило зменшити час на підготовку замовлення.

Першочерговим завдання для складських операцій під час пандемії стає оперативний і чіткий одночасний збір і відвантаження великої кількості замовлень. Тому, ефективна робота складу багато в чому залежить від персоналу складу підприємства та його мотивації на ефективну роботу.

Аналіз досліджень. В роботі [6] розглядається застосування методу «Фотографія робочого дня». Метод дозволяє визначити штатну чисельність працівників організації для оптимального розподілу посадових обов'язків.

В роботі [7] описано найбільш типові проблеми роботи складських комплексів, що перешкоджають ефективній організації складування, обробки вантажів, виконання замовлень клієнтів. Перераховано основні етапи роботи таких комплексів і аналізуються основні дії на кожному етапі. У роботі розглядаються проблеми ефективної роботи персоналу. Виділено етапи роботи по збільшенню ефективності функціонування персоналу, розглянуто проблеми, 3 якими можна зіткнутися при підвищенні ефективності роботи складу.

У роботі [8] розглядаються задачі про призначення, що виникають при формалізації різних прикладних проблем. Автори пропонують розв'язання я задач з додатковими обмеженнями загального вигляду, а також алгоритми розв'язання для багатокритеріальних задач.

В роботі [9] розглядається задача про призначення співробітників на окремі роботи інноваційного проекту. Запропоновано використовувати підхід, що дозволяє застосувати нечіткі множини для оцінки часу виконання робот по проекту за умови врахування індивідуальних особливостей співробітників, їх взаємодії та втоми.

Модель вибору кадрового забезпечення розроблена в роботі [10]. Модель дозволяє сформувати персонал офісу з урахуванням витратних критеріїв і кваліфікаційних, освітніх та психологічних якостей претендентів, які задано розмито.

Математична модель для порівняння кандидатів за результатами виконання тестових завдань 3 використанням теорії нечітких множин і нечіткої математики, що дозволяє формалізувати притаманні цьому процесу властивості суб'єктивності та невизначеності розроблена в роботі [11].

Задача про призначення широко використовується в прикладної діяльності і має множину інтерпретацій. Існують стандартні алгоритми пошуку оптимального рішення задачі про призначення 3 найпростішої лінійної моделлю, що дозволяють отримати точне рішення за поліноміальний час, наприклад, угорський метод [12]. Однак формулювання більшості прикладних задач про призначення не задовольняє найпростішої лінійної моделі. Часто запропоновані алгоритми рішення узагальнених задач про призначення характеризуються громіздкістю математичного апарату, який використовується, а також не завжди гарантують знаходження оптимального рішення, що може привести до значних 
економічних втрат в контексті багатьох прикладних задач. Але запропоновані математичні методи $\mathrm{i}$ моделі не відображають нечіткий характер взаємодії різних суб'єктів. Використання методів нечітких множин дозволить вирішувати задачу розподілу робіт на складі враховуючи психо-фізіологічні характеристики кожного співробітника.

Метою дослідження є підвищення ефективності роботи складу за рахунок розробки моделі розподілу робіт між працівниками із застосуванням нечітких множин, що враховує психо-фізіологічні характеристики кожного співробітника

Об'єктом дослідження є процеси розподілу робіт між працівниками.

Предметом дослідження є модель розподілу робіт між працівниками на складі із застосуванням нечітких множин.

Для досягнення поставленої мети необхідно виконати наступні задачі:

- розробити нечітку модель розподілу робіт між працівниками;

- привести приклад використання розробленої моделі розподілу робіт між працівниками на складі підприємства з застосуванням нечітких множин.

Розробка моделі розподілу працівників із застосуванням нечітких множин. Розглянемо нечітку модель розподілу робіт, які виконуються на складі підприємства.

Очевидно, що розподіляючи різні роботи, керівник приймає рішення суб'єктивно оцінюючи можливості та здатності кожного працівника, ступінь його освіченості, знайомства 3 предметною галуззю, досвід роботи, ті чи інші риси характеру, завантаженість працівника протягом усього робочого часу і т.д. Розглянемо загальну постановку задачі розподілу робіт на складі підприємства.

Відомо

- множина робіт $\mathrm{X}=\left\{\mathrm{x}_{1}\right\},(\mathrm{i}=\overline{1, \mathrm{~N}})$ на складі підприємства, яку необхідно виконати за деякій період часу;

- множина характеристик кожної роботи $\mathrm{Y}=\left\{\mathrm{y}_{\mathrm{j}}\right\},(\mathrm{j}=\overline{1, \mathrm{P}})$;

- множина працівників $\mathrm{Z}=\left\{\mathrm{z}_{\mathrm{k}}\right\},(\mathrm{k}=\overline{1, \mathrm{M}})$, які працюють на складі підприємства. Кожен працівник ідрізняється ступенем переваги по відношенню до тієї чи іншої роботи. Ці переваги визначаються багатьма факторами.

Необхідно оптимально розподілити всі роботи серед працівників, тобто для кожного працівника $\mathrm{z}_{\mathrm{j}}$ сформувати множину робіт $\mathrm{R}_{\mathrm{j}}\left\{\mathrm{x}_{\mathrm{i}}\right\}$, так щоб виконувалися вимоги $\bigcup_{\mathrm{j}} \mathrm{R}_{\mathrm{j}}\left\{\mathrm{x}_{\mathrm{i}}\right\}=\mathrm{X}$ та $\bigcap_{\mathrm{j}} \mathrm{R}_{\mathrm{j}}\left\{\mathrm{x}_{\mathrm{i}}\right\}=\varnothing$.

У загальному випадку для кожного виду робіт можна сформувати свій унікальний набір характеристик, але для простоти обчислень ми обмежимося лише декількома, найбільш загальними.

Кожній конкретній роботі та чи інша характеристика буде притаманний в деякій мірі.

Розглянемо, наприклад, характеристика «рівень кваліфікації». Рівень кваліфікації дозволяє співробітнику складу правильно розподілити робоче навантаження протягом всього робочого дня. Керівник може дати експертну оцінку значення функції приналежності конкретної роботи із всієї множини, які вимагають високої кваліфікації. Очевидно, що всі працівники складу мають різний рівень кваліфікації. Наприклад, для працівника, що має невеликий досвід роботи, вкрай важливим може бути характеристика «простота виконання», оскільки зі складною роботою він може не впоратися.

На першому кроці керівником складу проводиться експертна оцінка, яка дозволяє отримати формалізовану умову задачі.

Нехай $\mathrm{r}: \mathrm{X} \times \mathrm{Y} \rightarrow[0,1]-$ функція приналежності нечіткого бінарного відношення $\mathrm{R}$, що задається за допомогою експерта. Ця функція виражає, в якій мірі конкретні роботі хі властива характеристика $\mathrm{y}_{\mathrm{j}}$. Значення функції по конкретній роботі $\mathrm{x}_{\mathrm{i}}$ запишемо в рядок (вийде рядок з р елементів), розташуємо ці рядки один під одним (всього таких рядків n штук).

Отже, $\mathrm{R}$ - нечітке відношення «Робота - Характеристика роботи», яке в матричної формі має вигляд: 


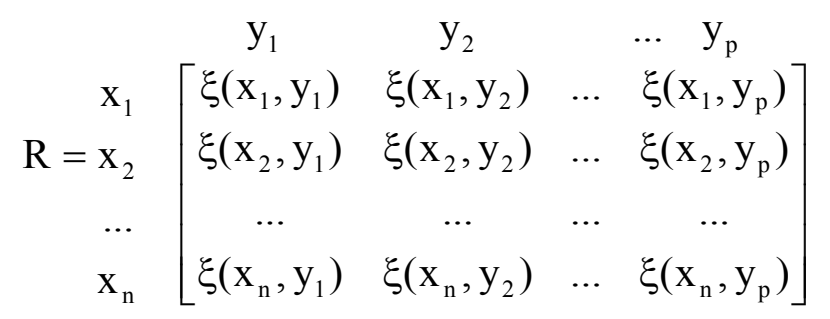

де $\xi\left(\mathrm{x}_{\mathrm{n}}, \mathrm{y}_{1}\right)$ функція приналежності нечіткого відношення $\mathrm{R}$, що відображає ступінь приналежності характеристики $\mathrm{y}_{\mathrm{j}}$ роботі $\mathrm{x}_{\mathrm{i}}$. Елементи кожного рядка матриці $\mathrm{R}$ показують, в якій мірі дана робота потребує наявності необхідних характеристик.

Нехай $\mathrm{s}: \mathrm{Y} \times \mathrm{Z} \rightarrow[0,1]-$ функція приналежності нечіткого бінарного відношення $\mathrm{S}$. Для всіх $\mathrm{y} \in \mathrm{Y}$ i всіх $\mathrm{z} \in \mathrm{Z} \cdot \mathrm{s}(\mathrm{y}, \mathrm{z})$ дорівнює ступеню важливості характеристики $\mathrm{y}_{\mathrm{i}}$ для працівника $\mathrm{z}_{\mathrm{j}}$. У матричній формі це відношення має вигляд:

$$
\begin{gathered}
\mathrm{y}_{1} \\
\mathrm{~S}=\mathrm{y}_{2} \\
\ldots \\
\mathrm{y}_{\mathrm{p}}
\end{gathered}\left[\begin{array}{cccc}
\psi\left(\mathrm{z}_{1}, \mathrm{z}_{1}\right) & \psi\left(\mathrm{y}_{1}, \mathrm{z}_{2}\right) & \ldots & \psi\left(\mathrm{z}_{1}, \mathrm{z}_{\mathrm{m}}\right) \\
\psi\left(\mathrm{y}_{2}, \mathrm{z}_{21}\right) & \psi\left(\mathrm{y}_{2}, \mathrm{z}_{2}\right) & \ldots & \psi\left(\mathrm{y}_{2}, \mathrm{z}_{\mathrm{m}}\right) \\
\ldots & \ldots & \ldots & \ldots \\
\psi\left(\mathrm{y}_{\mathrm{p}}, \mathrm{z}_{1}\right) & \psi\left(\mathrm{y}_{\mathrm{p}}, \mathrm{z}_{2}\right) & \ldots & \psi\left(\mathrm{y}_{\mathrm{p}}, \mathrm{z}_{\mathrm{m}}\right)
\end{array}\right]
$$

де $\psi\left(\mathrm{y}_{\mathrm{j}}, \mathrm{z}_{\mathrm{k}}\right)$ функція приналежності нечіткого відношення $\mathrm{S}$, що відображає ступінь важливості характеристики у для працівника $z$.

Іншими словами, матриця $\mathrm{S}$ відображає відносний ступінь важливості характеристик робіт $\mathrm{y}_{1}, \mathrm{y}_{2}$, ..., УР між працівниками $\mathrm{z}_{1}, \mathrm{z}_{2}, \ldots, \mathrm{z}_{\mathrm{M}}$ при виконання робіт множини $\mathrm{X}$.

Композиція $\mathrm{T}=\mathrm{R} \otimes \mathrm{S}$ бінарних нечітких відношень $\mathrm{R}$ i $\mathrm{S}$ дозволяє встановлює результуючий зв'язок між роботами та працівниками в формі нечіткого відношення «Робота - Працівник», що відображає ступінь переваги (можливості виконати) різні роботи (в залежності від їх характеристик) 3 боку працівників складу.

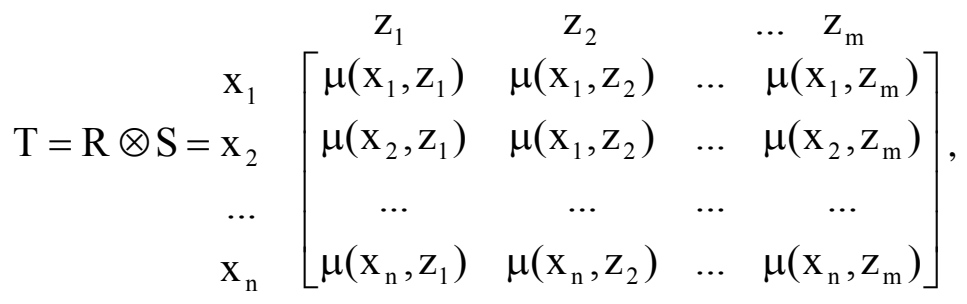

де $\mu\left(\mathrm{x}_{\mathrm{n}}, \mathrm{z}_{1}\right)$ - функція приналежності композиції нечітких відношень, що відображає ступінь переваги працівником $\mathrm{Z}_{\mathrm{k}}$ виконати роботу $\mathrm{x}_{\mathrm{i}}$, визначається за формулою [13]:

$$
\mu\left(x_{i}, z_{k}\right)=\frac{\sum_{j=1}^{P} \xi\left(x_{i} y_{j}\right) \otimes \psi\left(y_{i}, z_{k}\right)}{\sum_{j=1}^{P} \xi\left(x_{i} y_{j}\right)},(i=\overline{1, N} ; k=\overline{1, M})
$$

Сума $\sum_{\mathrm{j}=1}^{\mathrm{P}} \xi\left(\mathrm{x}_{\mathrm{i}} \mathrm{y}_{\mathrm{j}}\right)$ вказує на число найважливіших характеристик, які керівник використовує для оцінки роботи $\mathrm{x}_{\mathrm{i}}$. Таким чином, можна інтерпретувати як зважений ступінь прийнятності роботи $\mathrm{x}_{\mathrm{i}}$ для працівника $\mathrm{Z}_{\mathrm{k}}$. 
Далі визначається матриця попарних переваг $\mathrm{W}$, що показує ступінь прийнятності кожного виду роботи одночасно для кожної комбінації з двох працівників.

Матриця $\mathrm{W}$ дозволяє знайти поріг розподілу робіт, який визначається як ступінь прийнятності всієї множини робіт одночасно для всіх пар працівників.

Алгоритм обчислення порога розподілу робіт включає три кроки:

Крок 1. Визначаються максимальні значення за стовпцями матриці $\mathrm{W}$.

Крок 2. 3 них вибирається мінімальна величина $\omega$.

Крок 3. У матриці Т знаходиться найбільший елемент строго менший, ніж $\omega$, який і $є$ порогом поділу робіт $\lambda$.

Після того як поріг обрано, можна за стовпцями матриці $\mathrm{T}$ для кожного працівника $\mathrm{Z}_{\mathrm{k}}$ визначити рівневу множину L, тобто множину робіт, ступінь прийнятності якої для даної групи працівників перевищує або дорівнює порогу розподілу робіт $\lambda$.

Вага кожної групи працівників на складі, визначається за підсумками попередньої діяльності, задається ваговими функціями $\rho\left(\mathrm{z}_{\mathrm{k}}\right), \quad(\mathrm{k}=\overline{\mathrm{1}, \mathrm{M}})$. Вагові функції можуть вимірюватися у відсотках або в частках від загального обсягу робіт.

Розподіл робіт між працівниками описується зваженим об'єднанням рівневих множин $\mathrm{L}_{\mathrm{k}}$ :

$$
\mathrm{L}=\bigcup_{\mathrm{k}=1}^{\mathrm{p}} \rho\left(\mathrm{z}_{\mathrm{k}}\right) \mathrm{L}_{\mathrm{k}} .
$$

Схема нечітких відношень, яка використовується для розв'язання задачі представлена на рис. 1.

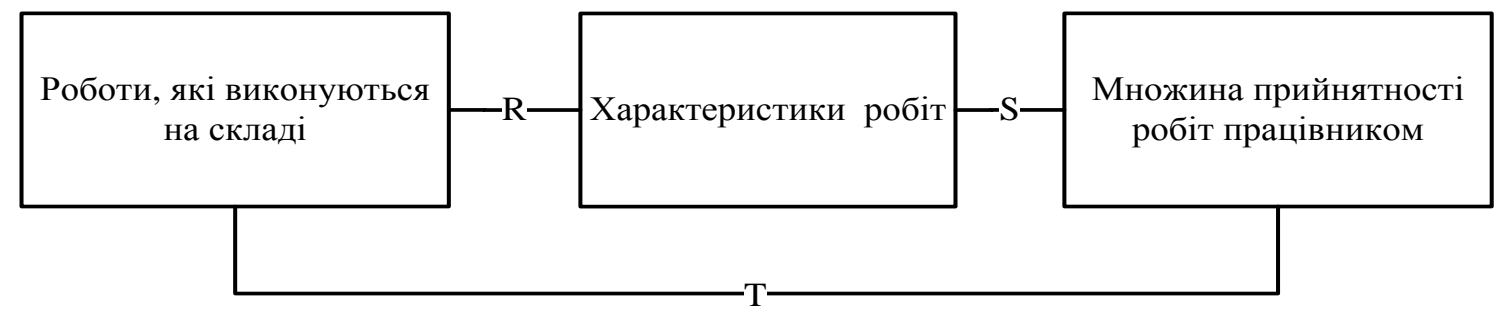

Рис. 1 Схема нечітких відношень в задачі розподілу робіт між працівниками

На наведеній схемі $\mathrm{R}$ - відношення приналежності характеристик робіт, $\mathrm{S}$ - відношення прийнятності характеристик робіт для працівників, $\mathrm{T}-$ відношення прийнятності працівників по роботах.

Розглянемо переваги використання даної моделі визначення розподілу робіт між працівниками на складі, заснованої на теорії нечітких відношень. Рішення задачі, допомагає керівнику оптимально розподілити роботи між працівниками відповідно до принципу поєднання можливості та бажаності, комплексно врахувати їх знання та досвід, а також знизити завантаженість.

Розглянемо приклад розподілу робіт між виконавцями складу підприємства 3 застосуванням теорії нечітких множин

Для ілюстрації розв'язання поставленої задачі розглянемо перелік робіт, які $є$ на складі. $\mathrm{x}_{1}-$ завідуючий складом; $\mathrm{x}_{2}-$ логіст; $\mathrm{x}_{3}$ - водій-експедитор; $\mathrm{x}_{4}-$ комірник; $\mathrm{x}_{5}-$ водій автонавантажувача.

Роботу можуть виконувати множина робітників, $\mathrm{Z}=\left\{\mathrm{z}_{1}, \mathrm{z}_{2}, \ldots, \mathrm{z}_{\mathrm{M}}\right\}: \mathrm{z}_{1}-$ Петров; $\mathrm{z}_{2}-$ Іванов; $\mathrm{z}_{3}$ - Сидоров; $\mathrm{z}_{4}-$ Васильєва; $\mathrm{z}_{4}-$ Кухтін.

Позначимо через $\mathrm{Y}=\left\{\mathrm{y}_{1}, \mathrm{y}_{2}, \ldots, \mathrm{y}_{\mathrm{P}}\right\}$ множину характеристик кожної роботи: $\mathrm{y}_{1}-$ швидкість $\mathrm{i}$ гнучкість мислення; у - $_{2}$ вміння швидко приймати рішення; у - стійкість і концентрація уваги; у4 зорова пам'ять; у - швидкість реакції; у6 - рухова пам'ять; у7 - фізична витривалість; у8 - координація руху; у9 - емоційного-вольова стійкість; у 10 - відповідальність.

Функції приналежності нечітких множин для відповідних робіт (посад) представлено на Рис.2. 


\begin{tabular}{|c|c|c|c|c|c|c|c|c|c|c|c|c|}
\hline 2 & & 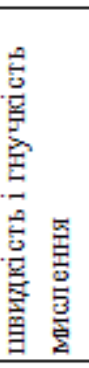 & 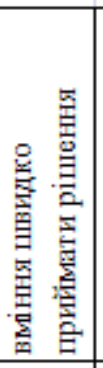 & 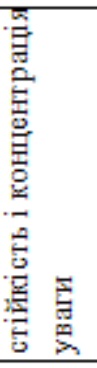 & 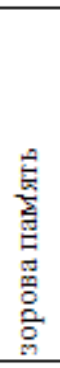 & 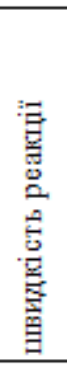 & 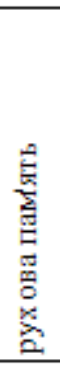 & 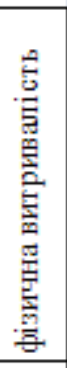 & 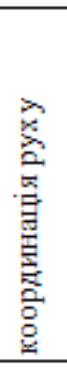 & 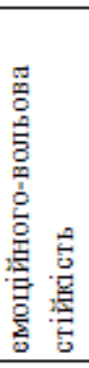 & 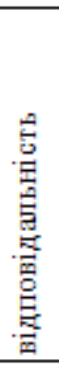 & Сума \\
\hline 3 & завідуючий складу & 0.9 & 0.9 & 0.8 & 0.4 & 0.5 & 0.4 & 0.5 & 0.2 & 0.9 & 0.9 & 6.4 \\
\hline 4 & логіст & 0.8 & 0.8 & 0.8 & 0.3 & 0.3 & 0.3 & 0.2 & 0.2 & 0.5 & 0.6 & 4.8 \\
\hline 5 & водій-експедитор & 0.5 & 0.5 & 0.5 & 0.6 & 0.9 & 0.8 & 0.9 & 0.8 & 0.7 & 0.7 & 6.9 \\
\hline 6 & комірник & 0.4 & 0.4 & 0.8 & 0.6 & 0.2 & 0.2 & 0.4 & 0.3 & 0.6 & 0.8 & 4.7 \\
\hline 7 & водій автонавантажувача & 0.3 & 0.3 & 0.5 & 0.3 & 0.8 & 0.7 & 0.8 & 0.8 & 0.3 & 0.3 & 5.1 \\
\hline
\end{tabular}

Рис. 2 Функції приналежності нечітких множин

Елементи матриці $\mathrm{R}$ показують, якою мірою кожна робота потребує різних характеристик у кандидатів на посади. відношення:

Представимо у матричному вигляді початкові дані функцій приналежності нечіткого

$$
\mathrm{R}_{=}=\begin{gathered}
\mathrm{x}_{1} \\
\mathrm{x}_{3} \\
\mathrm{x}_{4} \\
\mathrm{x}_{5}
\end{gathered}\left[\begin{array}{llllllllllll}
0,9 & 0,9 & 0,8 & 0,4 & 0,5 & 0,4 & 0,5 & 0,2 & 0,9 & 0,9 \\
0,8 & 0,8 & 0,6 & 0,3 & 0,3 & 0,3 & 0,2 & 0,2 & 0,5 & 0,6 \\
0,5 & 0,5 & 0,5 & 0,6 & 0,9 & 0.8 & 0,9 & 0,8 & 0,7 & 0,7 \\
0,4 & 0,4 & 0,8 & 0,6 & 0,2 & 0,2 & 0,4 & 0,3 & 0,8 & 0,8 \\
0,3 & 0,3 & 0,5 & 0,3 & 0,8 & 0,7 & 0,8 & 0,8 & 0,3 & 0,3
\end{array}\right] .
$$

Функції приналежності психофізіологічного профілювання кандидатів на посади представлено

\begin{tabular}{|c|c|c|c|c|c|}
\hline & 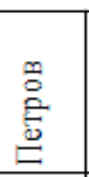 & 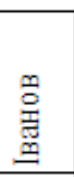 & 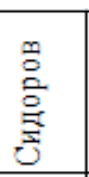 & 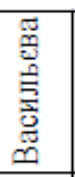 & 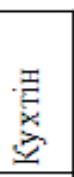 \\
\hline швидкість і гнучкіст & 0.9 & 0.8 & 0.7 & 0.9 & 0.7 \\
\hline вміння швидко прийм & 0.6 & 0. & 0.6 & 0.5 & 0.6 \\
\hline нщентрація & 0.5 & 0.2 & 0.3 & 0.8 & 0.7 \\
\hline зорова пам & 0.5 & 0.9 & 0.5 & 0.8 & 0.4 \\
\hline швидк & 0.9 & 0.6 & 0.5 & 0.6 & 0.4 \\
\hline рухова & 0.3 & 0.5 & 0.9 & 0.7 & 0.7 \\
\hline фізична витривал & 0.5 & 0.8 & 0.9 & 0.5 & 0.4 \\
\hline координація руху & 0.5 & 0.6 & 0.5 & 0.4 & 0.5 \\
\hline емоційного-вольова стї & 0.8 & 0.9 & 0.3 & 0.5 & 0.6 \\
\hline відповідальність & 0.3 & 0.5 & 0.5 & 0.6 & 0.8 \\
\hline
\end{tabular}
на Рис. 3.

Рис 3. Функції приналежності психофізіологічного профілювання кандидатів на посади

Представимо у матричному вигляді функції приналежності психофізіологічного профілювання кандидатів на посади. Матриця $\mathrm{S}$ відображає відносну ступінь важливості психофізіологічних характеристик $\mathrm{y}_{1}, \mathrm{y}_{2}, \ldots$, Ур у кандидатів $\mathrm{z}_{1}, \mathrm{z}_{2}, \ldots, \mathrm{z}_{\mathrm{M}}$ при розподілу на роботи $\mathrm{X}$. 


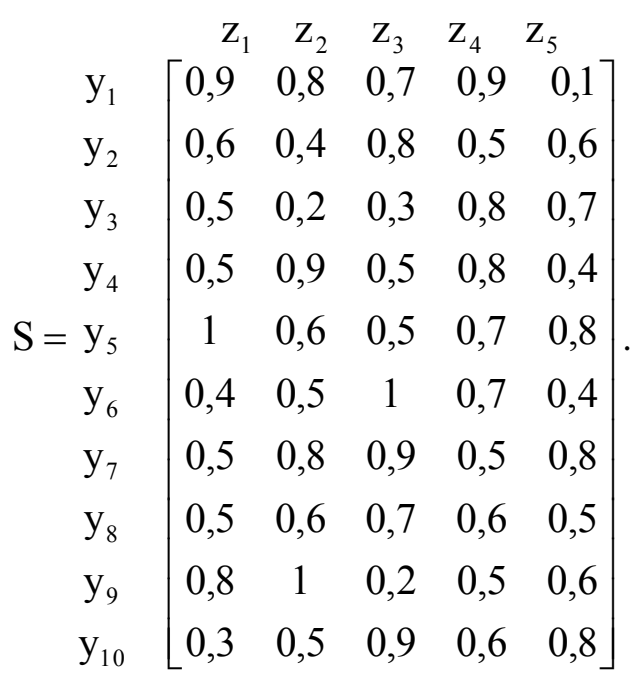

Результат обчислення матриці Т за формулою (3) представлено на Рис. 4.

\begin{tabular}{|c|c|c|c|c|}
\hline 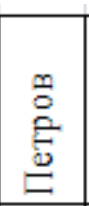 & 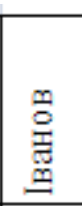 & $\begin{array}{l}\stackrel{\infty}{\circ} \\
\stackrel{\circ}{\circ} \\
\stackrel{\Xi}{\Xi}\end{array}$ & 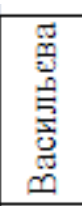 & 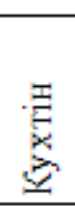 \\
\hline 0.60 & 0.61 & 0.55 & 0.64 & 0.61 \\
\hline 0.60 & 0.57 & 0.54 & 0.66 & 0.63 \\
\hline 0.58 & 0.63 & 0.59 & 0.61 & 0.57 \\
\hline 0.56 & 0.60 & 0.52 & 0.65 & 0.61 \\
\hline \begin{tabular}{|l|}
0.57 \\
\end{tabular} & 0.61 & 0.60 & 0.60 & 0.55 \\
\hline
\end{tabular}

Рис. 4. Розрахунок матриці T

Фактично в цій формулі в чисельнику стоїть число, яке вийшло б при знаходженні додатку матриць R та S, а в знаменнику - сума елементів відповідного рядка матриці R.

$$
\mathrm{T}=\begin{gathered}
\mathrm{x}_{1} \\
\mathrm{x}_{2} \\
\mathrm{x}_{3} \\
\mathrm{x}_{4} \\
\mathrm{x}_{5}
\end{gathered}\left[\begin{array}{cccccc}
0.6 & 0.61 & 0.55 & 0.64 & 0.61 \\
0.6 & 0.57 & 0.54 & 0.66 & 0.63 \\
0.58 & 0.63 & 0.59 & 0.61 & 0.57 \\
0.56 & 0.60 & 0.52 & 0.65 & 0.61 \\
0.57 & 0.61 & 0.60 & 0.60 & 0.55
\end{array}\right] .
$$

Далі визначається матриця попарних переваг W за формулою (Рис. 5).

$$
\mathrm{W}=\left[\begin{array}{ccc}
\min \left\{\mathrm{t}\left(\mathrm{x}_{1}, \mathrm{z}_{1}\right), \mathrm{t}\left(\mathrm{x}_{1}, \mathrm{z}_{2}\right)\right\} & \ldots & \min \left\{\mathrm{t}\left(\mathrm{x}_{1}, \mathrm{z}_{\mathrm{m}}\right), \mathrm{t}\left(\mathrm{x}_{1}, \mathrm{z}_{1}\right)\right\} \\
\ldots & \ldots & \ldots \\
\min \left\{\mathrm{t}\left(\mathrm{x}_{\mathrm{n}}, \mathrm{z}_{1}\right), \mathrm{t}\left(\mathrm{x}_{\mathrm{n}}, \mathrm{z}_{2}\right)\right\} & \ldots & \min \left\{\mathrm{t}\left(\mathrm{x}_{\mathrm{n}}, \mathrm{z}_{\mathrm{m}}\right), \mathrm{t}\left(\mathrm{x}_{\mathrm{n}}, \mathrm{z}_{1}\right)\right\}
\end{array}\right]
$$




\begin{tabular}{|c|c|c|c|c|}
\hline 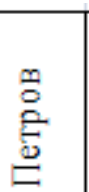 & 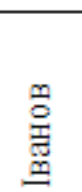 & 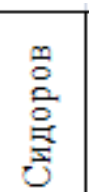 & 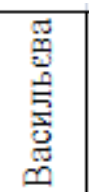 & 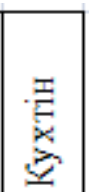 \\
\hline 0.60 & 0.55 & 0.55 & 0.61 & 0.60 \\
\hline 0.57 & 0.54 & 0.54 & 0.63 & 0.60 \\
\hline 0.58 & 0.59 & 0.58 & 0.57 & 0.57 \\
\hline 0.56 & 0.52 & 0.52 & 0.61 & 0.56 \\
\hline 0.57 & 0.60 & 0.57 & 0.55 & 0.55 \\
\hline
\end{tabular}

Рис. 5 Матриця попарних переваг W

$$
\mathrm{W}=\left[\begin{array}{lllll}
0.60 & 0.55 & 0.55 & 0.61 & 0.60 \\
0.57 & 0.54 & 0.54 & 0.63 & 0.60 \\
0.58 & 0.59 & 0.58 & 0.57 & 0.57 \\
0.56 & 0.52 & 0.52 & 0.61 & 0.56 \\
0.57 & 0.60 & 0.57 & 0.55 & 0.55
\end{array}\right] .
$$

У кожному стовпці матриці, отриманої на попередньому кроці, знаходимо максимальний елемент

$$
\mathrm{w}_{\text {max }}=\left(\begin{array}{lllll}
0.60 & 0.60 & 0.58 & 0.63 & 0.60
\end{array}\right) .
$$

3 них вибирається мінімальна величина $\omega=0.58$.

У матриці Т знаходиться найбільший елемент строго менший, ніж $\omega$, який і $є$ порогом поділу асортименту $\lambda=0.59$.

Після того як поріг обраний, можна за стовпцями матриці $\mathrm{T}$ для кожного кандидата $\mathrm{Z}_{\mathrm{k}}$ визначаємо рівневу множину, тобто множину робіт, ступінь прийнятності яких для кандидата перевищує або дорівнює порогу поділу робіт $\lambda$ (Рис. 6):

\begin{tabular}{|c|c|c|c|c|c|}
\hline & $\begin{array}{l}\stackrel{m}{\circ} \\
\stackrel{ }{\circ} \\
\stackrel{0}{\circ}\end{array}$ & 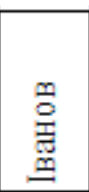 & 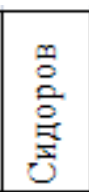 & 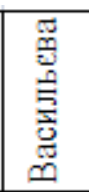 & $\underset{\Xi}{\stackrel{\Xi}{E}}$ \\
\hline завідуючий складу & 0.60 & 0.55 & 0.55 & 0.61 & 0.60 \\
\hline логіст & 0.57 & 0.54 & 0.54 & 0.63 & 0.60 \\
\hline водій-експедитор & 0.58 & 0.59 & 0.58 & 0.57 & 0.57 \\
\hline комірник & 0.56 & 0.52 & 0.52 & 0.61 & 0.56 \\
\hline водій автонавантажувача & 0.57 & 0.60 & 0.57 & 0.55 & 0.55 \\
\hline
\end{tabular}

$$
\mathrm{Q}_{1}=\left\{\mathrm{x}_{1}\right\}, \mathrm{Q}_{2}=\left\{\mathrm{x}_{5}\right\}, \mathrm{Q}_{3}=\left\{\mathrm{x}_{3}\right\}, \mathrm{Q}_{4}=\left\{\mathrm{x}_{1}, \mathrm{x}_{2}, \mathrm{x}_{4}\right\}, \mathrm{Q}_{4}=\left\{\mathrm{x}_{1}, \mathrm{x}_{2}\right\} \text {. }
$$

Рис. 6. Рекомендації з розподілу кандидатів на посади

Розглянуто задачу про призначення в разі декількох посад і декількох вакансій за допомогою методів нечіткої логіки, а саме за допомогою використання нечітких бінарних відношень.

Рішення задачі допоможе керівнику оптимально розподілити роботи між працівниками відповідно до принципу поєднання можливостей та бажаності працівників, комплексно врахувати їх знання та досвід, психофізіологічне профілювання, а також знизити їх завантаженість. 
Висновки та перспективи подальшого дослідження. Складська діяльність це частина інтегрованої логістичної системи підприємства. Склад є важливою ланкою, яка може вносить суттєві додаткові витрати у фінансову діяльність підприємства. На сучасному етапі у складських операціях на перше місце виходить не збереження товарів, а оперативний та чіткий одночасний збір і відвантаження великої кількості замовлень. Тому, ефективна робота складу багато в чому залежить від персоналу складу.

Розроблено нечітку модель розподілу робіт між працівниками. Наведено приклад розподілу робіт між працівниками на складі підприємства $з$ застосуванням теорії нечітких множин. Розрахунку виконувались у Microsoft Excel.

Наукова новизна: в роботі отримали подальший розвиток методи нечітких множин шляхом його поширення на нову предметну область розподіл робіт між працівниками.

Отримані результати будуть використані для розробки комп’ютерно-інтегрованої технології розподілу розподіл робіт між працівниками у вигляді програмно-методичних комплексів.

\section{Список бібліографічного опису}

1. Бойко Н.И. Погрузочно-разгрузочные работы и склады на железнодорожном транспорте: учебное пособие. М.: Учебнометодический центр по образованию на железнодорожном транспорте, 2011. 292 с.

2. Костюк О. С. Ефективне функціонування складської системи підприємства / О. С. Костюк, Н. Т. Гринів, М. В. Крук // Вісник Національного університету "Львівська політехніка". - 2010. - № 691 : Менеджмент та підприємництво в Україні: етапи становлення і проблеми розвитку. - С. 59-65.

3. Козлов, Е. Автоматизация складов: размер важнее содержания // ЛОГИСТИК\&система. - 2012.- № 6. - С.18-24.

4. Терехов, С.С. Как организовать работу на складе // Консультант директора. - 2011. - №3.- С.8-14.

5. Бейсултанова, Б. Р. Направления повышения эффективности складской деятельности коммерческого предприятия / Б. Р. Бейсултанова, В. В. Нордин. - Текст : непосредственный // Вопросы экономики и управления. - 2016. - № 3.1 (5.1). - С. 61-65. - URL: https://moluch.ru/th/5/archive/31/957/ (дата обращения: 01.10.2021).

6. Пивоварова В. В. Правильное распределение обязанностей - эффективная работа персонала организации // Современные тенденции в экономике и управлении: новый взгляд. - 2010. - №5-1. URL: https://cyberleninka.ru/article/n/pravilnoeraspredelenie-obyazannostey-effektivnaya-rabota-personala-organizatsii (дата обращения: 01.10.2021).

7. Зернов Е. В. Методы повышения эффективности работ складского комплекса // Economics. - 2017. - №2 (23). URL: https://cyberleninka.ru/article/n/metody-povysheniya-effektivnosti-rabot-skladskogo-kompleksa (дата обращения: 01.10.2021).

8. Лелякова, Л. В. Харитонова А. Г., Чернышова Г. Д. Прикладные задачи о назначениях (модели, алгоритмы решения) // Вестник Воронежского государственного университета, - 2017. - № 2. - С. 22 - 27.

9. Титов, Ю. Применение нечетко множеств для решения задач в назначение сотрудников на работы инновационного проекта. Научный взгляд в будущее, - 1(15-01), С. 40-44. URL: https://doi.org/10.30888/2415-7538.2019-15-01-036 (дата обращения: 01.10.2021).

10. Нефёдов Л. И., Петренко Ю. А., Кононыхин А. С. Модели выбора кадрового обеспечения офиса в условиях нечеткой информации // Вісник Національного технічного університету "ХПІ". Серія : Нові рішення в сучасних технологіях. 2014. № 26. C. 128-134.

11. Скороход С. В. Применение нечёткого подхода для оценки и подбора персонала // Исследовано в России. 2005. URL: https://cyberleninka.ru/article/n/primenenie-nechyotkogo-podhoda-dlya-otsenki-i-podbora-personala (дата обращения: 01.10.2021).

12. Никонов, О. Я., Подоляка О. А., Подоляка А. Н., Скакалина Е. В. Математические методы решения многокритериальной задачи о назначениях // Вісник Харківського національного автомобільно-дорожнього університету - 2011. № 5. С. 103 112.

13. Синкевич И. И., Медник В. И. Теория нечетких отношений как инструмент определения перспективного ассортимента // Управление экономическими системами, 2013. - 8 (56), C. 1-39: URL: https://ideas.repec.org/a/scn/007255/14932271.html (дата обращения: 01.10.2021).

\section{References}

1. Boiko N.I. Pogruzochno-razgruzochnye raboty i sklady na zheleznodorozhnom transporte: uchebnoe posobie [Loading and unloading operations and warehouses on railway transport: a textbook] (2011). Moscow: Uchebno-metodicheskii tsentr po obrazovaniiu na zheleznodorozhnom transporte, $292 \mathrm{p}$.

2. Kostjuk O. S., Gryniv N. T., Kruk M. V. Efektyvne funkcionuvannja sklads'koi' systemy pidpryjemstva [The effective functioning of enterprise warehousing system]. Visnyk Nacional'nogo universytetu "L'vivs'ka politehnika". 2010.vol. 691: Menedzhment ta pidpryjemnyctvo v Ukrai'ni: etapy stanovlennja i problemy rozvytku, pp. 59-65.

3. Kozlov, E. Avtomatizacija skladov: razmer vazhnee soderzhanija [Warehouse automation: size is more important than content]. LOGISTIK\&sistema. 2012. vol. 6. pp.18-24.

4. Terehov, S.S. Kak organizovat' rabotu na sklade [How to organize work in a warehouse] Konsul'tant direktora. 2011. vol. 3. pp. 814.

5. Beisultanova B., Nordin V.Napravlenija povyshenija jeffektivnosti skladskoj dejatel'nosti kommercheskogo predprijatija (2016) [Directions for improving the efficiency of warehousing activities of a commercial enterprise]. Molodoj uchenyj. vol. 10 (114). Available at: https://moluch.ru/th/5/archive/31/957/ (Accessed 01.10.2021).

6. Pivovarova V. Pravil'noe raspredelenie obiazannostei - effektivnaia rabota personala organizatsii (2010) [Proper distribution of responsibilities is the effective work of the organization's staff] Sovremennye tendentsii v ekonomike $i$ upravlenii: novyi vzgliad 
[Current trends in economics and management: a new look], vol. 5-1. URL: https://cyberleninka.ru/article/n/pravilnoeraspredelenie-obyazannostey-effektivnaya-rabota-personala-organizatsii (Accessed: 01.10.2021).

7. Zernov E. Metody povysheniia effektivnosti rabot skladskogo kompleksa (2017) [Methods of increasing the efficiency of the warehouse complex]. Economics. vol.2 (23). URL: https://cyberleninka.ru/article/n/metody-povysheniya-effektivnosti-rabotskladskogo-kompleksa (Accessed: 01.10.2021).

8. Leliakova, L. Kharitonova A., Chernyshova G. Prikladnye zadachi o naznacheniiakh (modeli, algoritmy resheniia) (2017)[ Applied assignment problems (models, solution algorithms)] Vestnik Voronezhskogo gosudarstvennogo universiteta, vol. 2. pp. 22 - 27.

9. Titov, Iu. Primenenie nechetko mnozhestv dlia resheniia zadach v naznachenie sotrudnikov na raboty innovatsionnogo proekta. (2019). [Application of fuzzy sets for the solution of tasks on fppointing employees to the works of the innovative Project] Nauchnyi vzgliad $v$ budushchee [Scientific look into the Future], vol. 1(15-01), pp. 40-44. doi:10.30888/2415-7538.2019-15-01036

10. Nefedov L. I., Petrenko Iu. A., Kononykhin A. S. Modeli vybora kadrovogo obespecheniia ofisa v usloviiakh nechetkoi informatsii [Models of office staffing in conditions of fuzzy information] Visnyk NTU "KhPI" [Bulletin of the National Technical University "KhPI"]. Kharkov, NTU "KhPI" Publ., 2014, no. 269, pp. 128-134.

11. Skorokhod S. V. Primenenie nechetkogo podkhoda dlia otsenki i podbora personala [Applying a fuzzy approach to staff evaluation and selection]. Issledovano $v$ Rossii [Researched in Russia]. 2005. URL: https://cyberleninka.ru/article/n/primenenienechyotkogo-podhoda-dlya-otsenki-i-podbora-personala (Accessed: 01.10.2021).

12. Nikonov, O., Podoliaka O., Podoliaka A., Skakalina E. Matematicheskie metody resheniia mnogokriterial'noi zadachi o naznacheniiakh [Mathematical methods of solving multicriterion assignment problem]. Bulletin of Kharkiv National Automobile and Highway University, 2011. no 5. pp. $103-112$.

13. Sinkevich I., Mednik V. Teoriia nechetkikh otnoshenii kak instrument opredeleniia perspektivnogo assortimenta [The theory of fuzzy relations as a tool for determining a promising range] Upravlenie ekonomicheskimi sistemami [Management of economic systems]. 2013. no 8 (56), pp. 1-39: URL: https://ideas.repec.org/a/scn/007255/14932271.html (Accessed: 01.10.2021). 